\title{
SOVEREIGN DEBT ISSUANCE CHOICE: SUKUK VS CONVENTIONAL BONDS
}

\author{
Rhada Boujlil ${ }^{1}$, M. Kabir Hassan ${ }^{2}$ and Rihab Grassa ${ }^{3}$ \\ ${ }^{1}$ Prince Sultan University, Saudi Arabia, rhada_joy@hotmail.com \\ ${ }^{2}$ University of New Orleans, USA, mhassan@uno.edu \\ 3 Manouba University, Tunisia, rihab_grassa@hotmail.fr
}

\begin{abstract}
This paper investigates the factors that determine governments' decisions to employ sovereign Sukuk over conventional bonds; the research is based on a sample of 143 Sukuk and 602 conventional sovereign bonds issued in 16 OIC countries between 2000 and 2015. The results depict that the nations that have developed financial markets, higher credit quality, and strong economic/financial prospects, issue more sovereign Sukuk than sovereign conventional bonds. Through the introduction of newly-developed debt tools, dealing with Sukuk bonds can diversify and develop current debt markets. However, less economically developed nations and countries are generally issuing insurance for classic sovereign bonds. Our findings suggest that governments' choice of sovereign debt is influenced mainly by national, financial, and macroeconomic indicators, as well as specific events. Countries with developed financial markets, strong economic indicators, high credit quality, and sustainable financial position are more likely to issue sovereign Sukuk than sovereign bonds as this strategy allows them to develop and diversify their financial markets through the promotion of new debt products.
\end{abstract}

Keywords: Financial instruments, Islamic finance, Sukuk, Sovereign debt issuance, Emerging countries.

JEL Classification: G20; G21; G32; P51; C33.

\author{
Article history \\ Received : September 13, 2019 \\ Revised : October 21, 2019 \\ Accepted : April 20, 2019 \\ Available online : May 20, 2020
}

https://doi.org/10.21098/jimf.v6i2.1104 


\section{INTRODUCTION}

\subsection{Background}

Debt financing is integral for both corporations and governments. While corporate debt financing has been extensively covered in the literature, its two major components, sovereign conventional bonds and sovereign Sukuk bonds, have only been tentatively discussed through the study of government debt financing. Debt financing, via Sukuk or conventional bonds, can be an important source of external funds for organisations and central governments alike. Sukuk, an alternative instrument of the conventional bond, has been endorsed by governments globally during the last twenty years (Haque et al., 2017).

The Sukuk market held a value of 134 million USD in 2000 and its value has increased to a value of 116.7 billion USD (IIFM Report, 2018). The market is saturated with emerging countries, especially those within the Organization of Islamic Cooperation (OIC). Western countries, such as the UK and Luxembourg, ventured into this market by issuing sovereign Sukuk in 2014. Indeed, sovereign Sukuk, issued by national governments, represents more than $55 \%$ of the Sukuk market. By the end of 2016, the total sovereign Sukuk issued rose to 472 billion USD (IIFM Report, 2017).

Recent research on the remarkable expansion of the Sukuk market provides information about the determinants of corporate Sukuk market development (Azmat et al., 2014; Klein \& Weill, 2016; Mohamed et al., 2015; Nagano, 2016, 2017; Said \& Grassa, 2013). Corporate Sukuk issuance is largely attributed to external and internal factors (Grigorian, 2003); it can be adversely affected by poor credit ratings and political conditions (Thomas, 2009) and country size (Gelos et al., 2011). Moreover, the choice between Islamic bonds and conventional bonds is attributed to the issuer and the bonds' characteristics (Grassa \& Miniaoui, 2017).

We conducted our research to capitalise on the gap in studies dedicated to investigating the dynamics of sovereign debt issuance by looking not only at conventional debt issue through sovereign bonds, but also Islamic debt issue via sovereign Sukuk. This is a growing Islamic finance instrument, which has also contributed to the growing literature on Sukuk. Our paper focuses on the factors and patterns that have caused the recent growth of the sovereign Sukuk market. Our empirical evidence shows that factors follow economic and finance theories.

The purpose of our paper is to address the following question: What are the dominant factors for sovereign debt issuers, such as the national government, to choose between conventional and Sukuk bond issuance? Sovereign or government debt is defined by how much a country owes to outside creditors and could be used interchangeably with public debt. Central governments usually issue sovereign or national debt as a way of measuring their financial growth and development projects, while relying on their stability and sovereign credit ratings to attract investors seeking sovereign debt investments.

Because sovereign debt arises due to accumulated annual deficits, historically, governments have employed a myriad of channels to finance their projects and raise funding. This has occurred through either directly borrowing from banks, institutions, individuals, or countries, or by issuing treasury bonds, bills, or notes. Governments of OIC countries, in particular, rely on different debt instruments or tools to meet their foreign debt needs. 
Nowadays, sovereign debt is an important cornerstone of many institutional investment portfolios and is considered to be among the safest investments in most countries. Sovereign bonds are safer than most other alternatives because countries strive to retain access to credit markets in the future and see it as high priority to pay back debt and avoid defaulting. This leads to governments carefully assessing the risks of undertaking sovereign debt, knowing that the sovereign debt default will strip countries of opportunities to obtain loans with favourable terms and conditions and interest rates in the future.

Defaulting also renders the defaulting country less creditworthy and forces it to directly borrow from international financial institutions (i.e. World Bank, IMF) at unfavourable interest rates, terms, and conditions. Although other financing project methods are available for central governments (i.e. raising taxes, reducing spending, and printing money), borrowing remains a favourable solution given that governments will always invest in new growth and development projects. Hence, there is a continuous rising demand for debt financing as a main avenue of funding for national governments.

The sample incorporates 745 sovereign issued debts, comprising 602 sovereign conventional bonds and 143 sovereign Sukuk bonds between 1995 and 2015 in 16 OIC countries, namely Algeria, Bahrain, Brunei Dar Al Salam, Egypt, Iraq, Jordan, Kuwait, Lebanon, Egypt, Malaysia, Morocco, Oman, Qatar, Saudi Arabia, Syria, Tunisia, and the UAE. Our findings provide evidence that issued sovereign Sukuk are larger than issued bonds and have longer maturities. Hence, sovereign bond issues are smaller and require higher margins to cover the potential risk involved. We provide evidence that financially and economically developed countries are more likely to issue sovereign Sukuk than conventional bonds. This preference tends to fuel issuing countries' diversification strategies and development of their current financial markets with the promotion of new debt tools. Conversely, lessdeveloped countries typically opt for traditional sovereign bond issuance. This preference towards classic debt tools is justified by the fact that these countries are not yet ready to venture into new sophisticated debt markets and are unwilling to try new debt tools such as Sukuk.

\subsection{Objective}

Our analysis is derived from different strands of the literature on sovereign debt, which helps us to contribute to the literature on a myriad of levels. First, given the unique and distinct features of conventional bonds compared with Islamic Sukuk, we enrich the literature by presenting evidence of how factors for issuing sovereign Sukuk and conventional debt may be similar but are different on many levels. Second, by comparing sovereign bonds with sovereign Sukuk characteristics across 16 OIC nations, the research also attempts to execute a comparative analysis on government issuance motives to understand why issuers prefer sovereign Sukuk. Third, we believe this is the first study that examines the association regarding the choice between credit quality and bond issuance, bearing in mind that a large body of literature is devoted to exploring the correlation between quality of credit and the decisions regarding public or private debt. Finally, we hope to add to the ongoing policy debate on the choice of government debt with a link between 
our empirical findings and real-world practices that assist policymakers. Our paper is organised as follows: Section 2 discusses the existing literature on the Sukuk market; Section 3 describes the data and methodology; Section 4 reviews the results and analysis; Section 5 discusses the regression results; and Section 6 provides a conclusion.

\section{LITERATURE REVIEW}

\subsection{Background Theory}

According to empirical studies exploring this phenomenon, the literature on the determinants of debt choice identifies an alarming stream of mixed results. The findings of Grigorian (2003) suggest that external and internal factors are significant. In a study that covers the initial and subsequent issues of emerging economies during the period 1980-2002, Grigorian identifies factors such as better fiscal position, lower levels of inflation, and higher levels of GDP per capita as a catalyst for selecting an issue type. Additional factors are identified by Thomas (2009), who claims that, during the period 1970-2006, LIDC's access to international capital markets was hindered by internal factors such as poor credit and external factors such as political instability.

Using a sample of 150 developing countries between 1980 and 2000, Gelos et al. (2011) singled out market access as a reason for choosing between sovereign bond issues or borrowing through private syndicated bank loans. They show that the economic size and prosperity of a country determine its access to the credit market. Not only do larger and richer countries have better access to credit markets, their organisations are of higher institutional quality, which drives their market access. While countries with bright financial and economic prospects have easy access to international credit markets, more vulnerable countries find it difficult to tap into them.

Similarly, the findings of Presbitero et al. (2016) suggest that factors such as a large economy, high GDP per capita, low public debt, and a highly effective government play a major role in increasing a country's likelihood of issuing bonds, compared to their non-issuing counterparts. On a global level, their results confirm previous evidence of the higher likelihood of issuances being associated with periods of sustainable global liquidity as well as higher commodity prices (especially in Sub-Saharan African nations).

\subsection{Previous Studies}

While most empirical data constitute conventional finance and developed capital markets, very recent data distinguishes between the debt issuance of Sukuk and conventional bonds. Most studies focus on the corporate level. For instance, Nagano (2017) suggests that choosing Sukuk issuance depends on one's access to the Sukuk market, which must be enabled before other determinants can promote its use. Once the issuer has full access to the Sukuk market, Sukuk issuance is promoted by the low degree of financial constraints on a firm and the level of a firm's undervaluation during the pre-issuance period. 
Sukuk issuance may be preferred along with market timing, given that the hierarchy of market accessibility is complete. Klein and Weil (2015) present evidence that information asymmetries and adverse selection impact market choice. Godlewski et al. (2013) studied stock market investor reactions when Sukuk issuance was employed in Malaysia. The study found a negative market reaction, which indicates that Sukuk did not give a positive signal to the issuer. Due to its nature, Sukuk allures riskier firms with less profitable projects, reinforces the information asymmetries surrounding a debt market, and exposes it to moral hazards and adverse selection problems.

In a subsequent study to further investigate the negative market reaction, Godlewski, Turk-Ariss and Weill (2016) delve into this negative reaction and, with a sample of Sukuk from eight different countries, examine the influence of the Sharia board on shareholder reactions. For it to be issued, Sukuk must be approved by a religious committee to confirm it follows Islamic law. The importance of scholar acceptance exposes Sukuk to an unseen Sharia-compliance risk compared to conventional bonds, which exacerbates the differences.

Azmat et al. (2014) suggest that, unlike conventional bonds, a Sukuk bond issuer's stock valuation has no impact on the debt-equity targets associated with bond issuance from an Islamic joint venture, and that Islamic partnership-based bond shares are quite dissimilar to equity. Their findings also suggest that bond security and seniority should be the main focus of bond issuers in lieu of their Islamic structure. They find that security against real asset bonds does not always dictate who or what owns the actual asset.

Mohamed et al.'s (2015) findings uphold the trade-off theory, which is conveyed through the optimising behaviour of firms among issuers of Sukuk and conventional bonds; however, they have different issuance motives. The authors suggest that this is chosen when firms are faced with higher information asymmetry costs. In addition, their findings support that the pecking order theory is implemented by issuers of partnership-based Sukuk and its convertible bonds. In addition, although straight bond issuers and exchange-based Sukuk may share the same goal or target, the trade-off view remains the choice of firms that enjoy higher sales growth.

Most previously cited works concentrate on the corporate choice of debt between sovereign Sukuk and conventional bonds. However, to our knowledge, this is the first study to investigate the determinants of governments' employment of debt when comparing sovereign Sukuk and sovereign bonds. Therefore, we add to the research on the Sukuk market by extending several previous empirical works and by approaching a novel research area.

\section{METHODOLOGY}

\subsection{Data}

We investigated the sovereign Sukuk and bond market in 16 Muslim countries, namely Algeria, Bahrain, Brunei Dar Al Salam, Egypt, Iraq, Jordan, Kuwait, Lebanon, Egypt, Malaysia, Morocco, Oman, Qatar, Saudi Arabia, Syria, Tunisia and the UAE, with issuances during the period 1995-2015 (See Table 1). The main source of data is the Zawya database, which is a section of Thomson Reuters Middle 
East and a reliable source of regional news, intelligence, company databases, and information on the latest projects from across the MENA region. We utilised the Zawya database for data on bonds and Sukuk options based on issuance size, specific issuance year, tenor, credit rating, date of issuance, and financing deal type and/or contract.

Following Grassa and Miniaoui (2017), we then matched the sovereign conventional bond and Sukuk issuances with the issuing country's economic and financial characteristics within the same year. We matched the issue of each country, given the year of issuance between 1995 and 2015, with its corresponding macroeconomic indicators (economic size and growth, interest rate, inflation rate, finance debt, and cumulative finance debt) in addition to its financial characteristics (the size of the Islamic banking system, financial market size, capital market size, financial market development indicator, institutional indicator, institutional reserves, and country credit rating) (see Table 3). This information was collected from multiple sources such as the Global Competitiveness Reports published by the IMF and the World Bank's Global Development Finance (GDF) database. We used the Zawya database to construct data on simultaneous and previous issuances of sovereign Sukuk and bonds, and collected historical data for the participating countries regarding any previous sovereign defaults they had experienced.

As part of investigating the determinants of government debt choice between sovereign bonds and Sukuk issuances, and to stay true to the comparative analysis between sovereign conventional bonds and Sukuk, we have chosen to remove hybrid bond issuances (asset-backed bonds and convertibles), while including all Sukuk types.

We ended up with an unbalanced panel of data; this was due to the fact that the countries in our sample had distinctive issues of either sovereign conventional bonds or Sukuk throughout the sampling period. Our final sample contains a total of 745 issuances made by 16 countries during the period 1995-2015; sovereign Sukuk represents $18.4 \%$ of the sample in terms of issues, making the total number of issued sovereign bonds to be substantially inferior to the number of sovereign bonds. Table 1 presents the types of issuance per year.

Table 1.

Sample Distribution of Issues by Year

\begin{tabular}{lcc}
\hline & Bonds & Sukuk \\
\hline 1995 & 3 & 0 \\
1996 & 3 & 0 \\
1997 & 4 & 0 \\
1998 & 6 & 0 \\
1999 & 3 & 0 \\
2000 & 5 & 0 \\
2001 & 4 & 0 \\
2002 & 4 & 1 \\
2003 & 8 & 1 \\
2004 & 4 & 1 \\
2005 & 7 & 4 \\
\hline
\end{tabular}


Table 1.

Sample Distribution of Issues by Year (Continued)

\begin{tabular}{lcc}
\hline & Bonds & Sukuk \\
\hline $\mathbf{2 0 0 6}$ & 12 & 4 \\
$\mathbf{2 0 0 7}$ & 7 & 2 \\
$\mathbf{2 0 0 8}$ & 18 & 1 \\
$\mathbf{2 0 0 9}$ & 21 & 4 \\
$\mathbf{2 0 1 0}$ & 22 & 5 \\
$\mathbf{2 0 1 1}$ & 25 & 7 \\
$\mathbf{2 0 1 2}$ & 45 & 19 \\
$\mathbf{2 0 1 3}$ & 113 & 25 \\
$\mathbf{2 0 1 4}$ & 157 & 30 \\
$\mathbf{2 0 1 5}$ & 131 & 39 \\
\hline Total & $\mathbf{6 0 2}$ & $\mathbf{1 4 3}$ \\
\hline
\end{tabular}

Table 2 shares the descriptive statistics of sovereign Sukuk and bond issuances. We observe that sovereign Sukuk are, on average, larger than sovereign bonds. The average margin of the sovereign bonds is higher than that observed with sovereign Sukuk. However, the median maturity of sovereign debt is considerably and substantially longer for sovereign Sukuk issuances.

The results indicate that both sovereign Sukuk and conventional bond markets may be highly differentiated; this is naturally inherited from the fact that governments have different needs for financing. Results also show that the market is strongly segmented, with sovereign bond issuers dominating their Sukuk issuing counterparts. This may be linked to the potential view that it is the economic and financial underlying circumstances within issuing countries that mandate the type of issuance.

\section{Sovereign Conventional Bonds:}

Table 2.

Descriptive Statistics by Issuance Type

\begin{tabular}{lccccc}
\hline Variable & Mean & Median & St. Dev. & Min & Max \\
\hline Size & 1.881 .508 & 1.847 .831 & 1.568 .661 & 1.312 .835 & 2.239 .722 \\
Margin & 6.066 .744 & .05254 & 3.598 .922 & .473 & 17 \\
Tenor & 6.462 .063 & 5 & 5.602 .524 & 1 & 30 \\
Previous Issue & .1143847 & 0 & .3185542 & 0 & 1 \\
Simultaneous Issue & .0833333 & 0 & .2766256 & 0 & 1 \\
Sovereign Default & .4540728 & 0 & .4983182 & 0 & 1 \\
Regulation & 3.918 .216 & 3.9 & .551655 & 2.4 & 5.2 \\
Institutional Quality & 430.048 & 4.4 & .703654 & 2.657 .816 & 5.945 .494 \\
Institutional Reserves & $8.53 \mathrm{e}+08$ & $9.31 \mathrm{e}+08$ & $2.91 \mathrm{e}+09$ & $-5.79 \mathrm{e}+0$ & $5.04 \mathrm{e}+09$ \\
Finance Debt & 6.294 .988 & 6.682 .353 & 1.574 .261 & 1.900 .876 & 8.578 .853 \\
Cumulative Finance Debt & 194115 & 86093 & 232561.3 & 0 & 795741 \\
Credit Rating & 6.095 .486 & 5 & 1.518 .436 & 5 & 9 \\
\hline
\end{tabular}


Table 2.

Descriptive Statistics by Issuance Type (Continued)

\begin{tabular}{lccccc}
\hline Variable & Mean & Median & St. Dev. & Min & Max \\
\hline GDP & $1.13 \mathrm{e}+11$ & $5.57 \mathrm{e}+10$ & $1.05 \mathrm{e}+11$ & 1.982 .548 & $6.72 \mathrm{e}+11$ \\
\hline Interest Rates & 4.381 .698 & 4.716 .667 & 1.060 .882 & 16.425 & 5.741 .667 \\
\hline INF & 4.474 .513 & 3.271 .702 & 3.119 .531 & .5833084 & 101.458 \\
\hline GDP Per Capita & 10513.79 & 3.976 .966 & 12651.16 & 2.653 .899 & 38184.86 \\
\hline Islamic Finance Size & 1.007 .911 & 9.625 .743 & 7.837 .695 & 1.794 .681 & 2.967 .921 \\
\hline Fin. Mkt Size & 6.648 .266 & 7.132 .864 & 315.326 & 6.925 .822 & 1.790 .929 \\
\hline Capital Market Size & 5.755 .331 & 6.763 .248 & 2.548 .456 & 8.350 .541 & 1.562 .479 \\
\hline
\end{tabular}

Table 2 showcases the major summary statistics of our data: the mean, median, standard deviation, minimum, and maximum. The number of issues is represented in USD millions. Maturity is expressed in number of years.

\section{Sovereign Sukuk:}

\begin{tabular}{lccccc}
\hline Variable & Mean & Median & St. Dev. & Min & Max \\
\hline Size & 19.79941 & 20.29248 & 1.194095 & 17.12075 & 21.37686 \\
Margin & 4.149453 & .03899 & 1.653025 & .18 & 11.25 \\
Tenor & 7.23209 & 6.75 & 5.985642 & .2 & 34 \\
Previous Issue & .9323308 & 1 & .252127 & 0 & 1 \\
Simultaneous Issue & .2932331 & 0 & .4569655 & 0 & 1 \\
Sovereign default & 0 & 0 & 0 & 0 & 1 \\
Regulation & 5.197222 & 5.2 & .3667874 & 4.3 & 5.6 \\
Institutional Quality & 5.140226 & 5.1 & .33627 & 4.526371 & 5.945494 \\
Institutional Reserves & $-5.72 \mathrm{e}+08$ & $-6.58 \mathrm{e}+08$ & $4.60 \mathrm{e}+09$ & $-5.79 \mathrm{e}+09$ & $5.04 \mathrm{e}+09$ \\
Finance Debt & 49.64918 & 5.267 .475 & 10.04901 & 0 & 54.49153 \\
Cumulative Finance & 354400 & 460718 & 197318.9 & 946 & 548990 \\
Debt & & & & & \\
Credit Rating & 8.164179 & 8 & .6276107 & 7 & 10 \\
GDP & $2.72 \mathrm{e}+11$ & $2.97 \mathrm{e}+11$ & $1.34 \mathrm{e}+11$ & $1.44 \mathrm{e}+10$ & $6.50 \mathrm{e}+11$ \\
Interest Rates & 2.414635 & 1.805 & 1.073426 & 1.6425 & 5.741667 \\
INF & 2.425594 & 2.097 & .8610653 & .5833084 & 5.440782 \\
GDP Per Capita & 17512.99 & 10878.39 & 10861.29 & 8236.022 & 38184.86 \\
Islamic Finance Size & 12.8957 & 11.08931 & 10.42141 & 1.794681 & 29.67921 \\
Financial Market Size & 118.6687 & 129.2603 & 30.54438 & 35.53503 & 168.0671 \\
Capital Market Size & 109.8746 & 129.008 & 36.35128 & 26.08485 & 147.9527 \\
\hline
\end{tabular}

\subsection{Method}

To investigate what determines the choice between sovereign Sukuk or bonds, in this research, we have chosen to employ a specific econometric technique for dynamic panel data models (DPDs) by merging time series and cross-sectional data characteristics. In similar studies, the literature tends to use the Probit model as advanced by Greene (2003) and Kumar et al. (2010); it is based on a binary 
outcome dependent variable for which the predicted probabilities are limited to between 0 and 1 . In fact, because the Probit model specifies a binary response, it is perfect for establishing a connection between the discrete variable and its determinants. However, for modelling techniques involving the Probit model, the latter may suffer from unobserved heterogeneity and/or endogeneity flaws. Moreover, traditional techniques have been widely used in a myriad of previous studies, such as the two-stage procedure (2SLS) destined to estimate the partial adjustment debt model (Byoun, 2008; Fama \& French, 2002; Frank \& Goyal, 2003).

Interestingly, critics for the former econometric techniques have emerged, who blame them for producing biased estimates in dynamic panel data models, especially when panel lengths are short or when individual firm fixed-effects are present (Baltagi, 2008; Huang \& Ritter, 2009; Laisney \& Lechner, 2003; Lemmon et al., 2008).

Therefore, in this study, we adopt the largely popular Logit model to analyse the binary outcome dependent variable, i.e. governments' choice of sovereign debt. The Logit model is a binary outcome model that has a different functional form to the Probit model. Binary models are among the most popular in applied economics; the model estimates the probability that $\mathrm{Y}$, the dependent variable, is a binary outcome, with $Y=1$ as a function of the explanatory variables. In the Logit model, we model the probability of $Y=1$, so instead of modelling the value of $Y$ itself, we are modelling the probability that $\mathrm{Y}$ would be taking the value of 1 ; in this case, we identify government's choice of debt to be the issuance of sovereign Sukuk when $\mathrm{Y}=1$.

$\mathrm{Y}=$ The government's choice of sovereign debt as:

$\mathrm{Y}=1$ if the choice of debt is sovereign Sukuk

0 if the choice of debt is sovereign conventional bonds.

Our conjecture espouses that the government's choice of sovereign debt is influenced by four major variable categories:

- Specific issue characteristics

- The country's macroeconomic indicators, i.e. economic characteristics

- The country's financial development indicators, i.e. financial characteristics

- $\quad$ Specific events

Finally, we estimate the following equations using our data:

$\mathbf{y i}^{*}=\alpha+\beta 1$ Size $+\beta 2$ Margin $+\beta 3$ Tenor $+\beta 4$ GDP $++\beta 5$ Capital Market Size + $\beta 6$ Financial Market Size $+\beta 7$ Islamic Finance Size $+\beta 8$ Previous Sukuk Issuance $+\beta 9$ Simultaneous Sukuk Issuance $+\beta 10$ Sovereign Default $+\beta 11$ Regulation + $\beta 12$ Institutional Quality $+\beta 13$ Institutional Reserves $+\beta 14$ Finance Debt $+\beta 15$ Cumulative Finance Debt $+\beta 16$ Rating $+\beta 17$ GDP $+\beta 18$ GDP Per Capita $+\beta 19$ Inflation $+\beta 20$ Interest Rate $+\varepsilon$

*In the model, sovereign Sukuk (with $\mathrm{Yi}=1$ ) is the base case with which the sovereign bond (with $\mathrm{Yi}=2$ ) options are compared. 
Table 3.

Data source

\begin{tabular}{|c|c|c|}
\hline Variables & Measured by & Source \\
\hline \multicolumn{3}{|l|}{ Issue Characteristics } \\
\hline Issuance Size (Size) & Log of total amount issued & Zawya database \\
\hline Issuance Tenor (Tenor) & Number of years & Zawya database \\
\hline Margin (Margin) & Margin percentage & Zawya database \\
\hline \multicolumn{3}{|l|}{ Macroeconomic Indicators } \\
\hline \multirow[t]{2}{*}{ Economic size ( GDP ) } & $\begin{array}{l}\text { GDP at purchasing power parity } \\
\text { (EC size)/ }\end{array}$ & World Bank \\
\hline & Population (POP) & \\
\hline Interest rates (INTER) & $\begin{array}{l}\text { Interest rate spread(lending rate } \\
\text { minus LIBOR) }\end{array}$ & World Bank \\
\hline Inflation (INF) & Inflation Rate & World Bank \\
\hline $\begin{array}{l}\text { The economic growth } \\
\text { (GDP per capita) }\end{array}$ & GDP per capita & World Bank \\
\hline Finance Debt (FDEBT) & $\begin{array}{l}\text { Central government debt to GDP } \\
(\%)\end{array}$ & World Bank \\
\hline Cumulative Finance Debt & $\begin{array}{l}\text { Equal to total finance debt in the } \\
\text { last } 3 \text { years }\end{array}$ & World Bank \\
\hline \multicolumn{3}{|l|}{ (Cumulative F. D.) } \\
\hline \multicolumn{3}{|l|}{ Financial Development Indicators } \\
\hline $\begin{array}{l}\text { Islamic banking system size } \\
\text { (IFSIZE) }\end{array}$ & Islamic financial assets to GDP & Grassa and Gazdar (2013) \\
\hline Financial Market size (FINMART) & $\begin{array}{l}\text { Financial system deposits to GDP } \\
(\%)\end{array}$ & World Bank \\
\hline $\begin{array}{l}\text { Capital market capitalization } \\
\text { (CAPMART) }\end{array}$ & Stock market & World Bank \\
\hline Regulation & $\begin{array}{l}\text { Financial market development } \\
\text { indicator score (1-7) }\end{array}$ & World Competitiveness Report \\
\hline Institutional Quality & $\begin{array}{l}\text { the Institutions Indicator (a score } \\
\text { of 1-7) }\end{array}$ & $\begin{array}{c}\text { World Competitiveness } \\
\text { Report }\end{array}$ \\
\hline Institutional Reserves & (months of imports) & World Bank \\
\hline Country credit rating & Rating & S\&P Rating Agency \\
\hline \multicolumn{3}{|l|}{ Events } \\
\hline Previous Sukuk Issuance & $\begin{array}{l}\text { Dummy variable equals } 1 \text { when } \\
\text { the government } i \text { has experienced } \\
\text { Sukuk issuance in the past } 3 \\
\text { years, and } 0 \text { otherwise. }\end{array}$ & Zawya Database \\
\hline Simultaneous Issuance & $\begin{array}{l}\text { Dummy variable equals to } 1 \text { if } \\
\text { the government has issued both } \\
\text { sukuk and conventional bond in } \\
\text { the same year. }\end{array}$ & Zawya Database \\
\hline Sovereign Default & $\begin{array}{l}\text { Dummy variable equals to } 1 \text { if the } \\
\text { government has experienced a } \\
\text { sovereign default } 0 \text { otherwise. }\end{array}$ & World Bank \\
\hline
\end{tabular}


Table 3 establishes the guidelines for our data variables and their respective sources. We identify four distinct categories as possible reasons for a government's choice of sovereign debt (specific issue characteristics, the country's macroeconomic indicators, the country's financial development indicators, and specific events).

As far as issue characteristics are concerned, a government's issue size is measured by taking the log of the total amount of issued debt; the issuance tenor refers to the number of years that the debt is held for; and the margin represents the amount of collateral the holder of the debt is obligated to deposit with a counterparty to cover all or part of the credit risk exposure. Macroeconomic indicators include economic size and growth, which are depicted through GDP and GDP per capita respectively; interest rates represent the resulting spread of the lending rate minus LIBOR ; inflation is proxied by the inflation rate; finance debt is represented through the ratio of central government debt to GDP; and cumulative finance debt is the total finance debt from the last three years. The characteristics of financial development indicators encompass the size of Islamic banking systems as the ratio of Islamic financial assets to GDP; the size of the financial market size as the percentage of financial system deposits to GDP; market capitalisation of the stock market; regulation represented through the financial market development indicator score; the institutional quality represented by countries' institutions indicator; institutional reserves depicted by the import months; and the countries' credit rating as provided by the S\&P credit rating agency. Finally, the events we consider in this study can be categorised under previous Sukuk issuance - a dummy variable equal to 1 when the government has experienced Sukuk issuance in the past three years, and 0 otherwise; simultaneous issuance - a dummy variable that equals 1 if the government has issued both Sukuk and conventional bonds in the same year, the event of sovereign default -another dummy variable that equals 1 if the government has experienced sovereign defaults, and 0 otherwise.

\subsection{Hypotheses Development}

As part of our effort to investigate what determines governments' choice of sovereign debt channel, we follow the popular conventional finance view of Grigorian (2003), which is that both external and internal factors are significant when considering debt. We hypothesise that analogous to firms seeking debt, a plethora of internal and external factors do affect governments' choice of sovereign debt. Internal factors may emerge from the country's own financial characteristics as conveyed by its financial development indicators, its financial characteristics, or the specific events the country experiences, for instance, whether it is a previous sovereign default or a simultaneous issue of sovereign conventional and Sukuk.

Hypothesis 1: Both internal and external factors matter in governments' choice of sovereign debt.

According to Gelos et al. (2011), larger and wealthier nations have better access to credit markets. In line with this view, we agree that countries with developed credit markets, larger financial markets, greater finance debt, and higher country credit ratings may have better incentives to develop their current credit markets through their access to newly-developed credit instruments, i.e. sovereign Sukuk, 
so they are more likely to issue sovereign Sukuk bonds than sovereign conventional bonds.

Hypothesis 2: Larger and richer countries are more likely to issue sovereign Sukuk bonds than sovereign conventional bonds.

Following Presbitero et al. (2016), we believe that several determinants interact to influence a country's choice of sovereign debt. We hypothesise that the choice of sovereign debt hinges on a plethora of factors, such as the level of a country's economic development as shown by its economic indicators (economic size and growth) and its financial characteristics (the level of finance debt, size of the financial market, size of the Islamic banking system, quality of institutions and reserves, and country credit rating, etc).

Hypothesis 3: A government's preference for a sovereign debt mechanism is influenced by financial development indicators and macroeconomic indicators.

Nagano (2017) argues that to choose Sukuk over conventional bond issuance, it necessary to be able to access the Sukuk market; a low level of financial constraints may lead to a preference for the Sukuk market. We posit that countries that benefit from larger Islamic finance systems and favourable country credit ratings are more inclined to issue sovereign Sukuk.

Hypothesis 4: Countries with larger Islamic finance systems and favourable country credit ratings display a higher probability of issuing sovereign Sukuk than sovereign conventional bonds.

Godlewski et al. (2013) suggest that the issuance of Sukuk may give a signal to the public. We concur that specific events within a country may impact on the type of debt issuance because countries experience different circumstances.

Hypothesis 5: Countries with simultaneous or previous issuance are more likely to issue Sukuk bonds than conventional bonds.

\section{RESULTS AND ANALYSIS}

This section showcases the results of the study and makes relevant comments. We present our main findings, additional results, and robustness checks. 


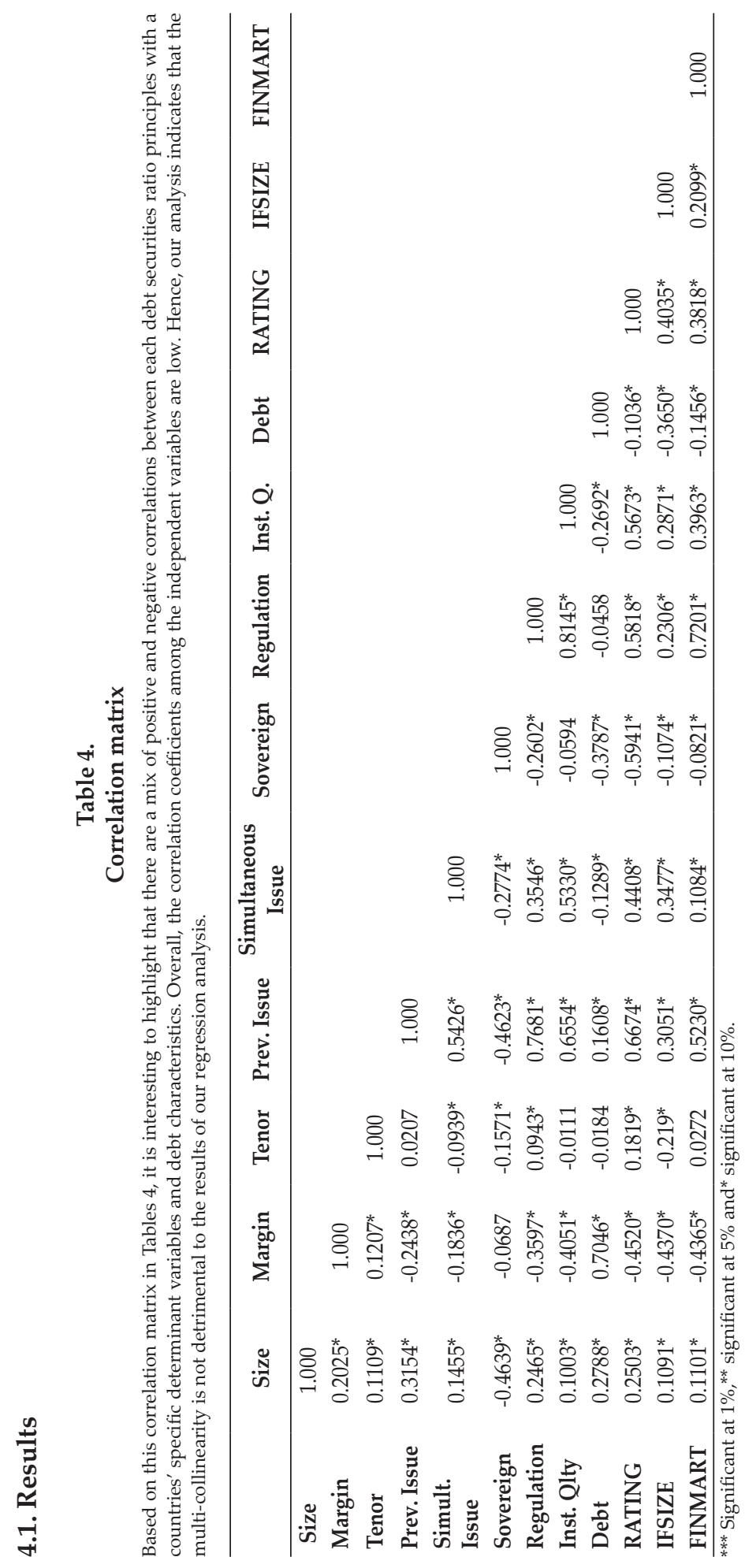


A mix of positive and negative correlations between the variables in our main equation emerge from the correlation matrix in Table 4; we notice that the correlation coefficients of the independent variables are mainly low, which indicates that multi-collinearity is not a detrimental issue to our regression analysis results.

On the one hand, the correlation matrix shows a negative and significant correlation between an OIC country's credit rating and margin (-0.4520), which justifies that countries with a low credit rating are less credible or less creditworthy; they are then required to present higher margins to cover some or all of the potential credit risk exposure. On the other hand, a country's debt and the size of its financial market are negatively and significantly correlated at the $10 \%$ significance level (-0.1456), which indicates that countries with strong financial markets have lower levels of debt or rely less on debt markets to fulfil their financing needs. A country's credit rating and its level of debt are negatively correlated $(-0.1036)$, which indicates that an OIC country's credit market accessibility hinges on its sovereign credit rating score and confirms the above findings, i.e. the better a country's credit quality, the less it relies on debt channels, even though it has greater access to the credit market.

The size of the Islamic banking system for an OIC country is negatively correlated with its level of debt (-0.3650), which indicates that countries with higher dependence on government debt financing are less likely to tap into the Sukuk market and are more likely to prefer the regular conventional bond issuance. Moreover, an OIC country's credit rating and the size of its Islamic banking system are significantly and positively correlated at a $10 \%$ significance level (0.4035). This indicates that OIC countries with relatively higher credit quality tend to prefer issuing sovereign Sukuk than conventional bonds. This strategy may be linked to the willingness of those countries to explore and take advantage of newly developed credit tools as part of developing and revolutionising their own credit markets.

The size of Islamic finance and margins are negatively correlated (-0.4370), i.e. countries that rely on sovereign Sukuk as a major source of financing are required to retain lower margins, unlike their counterparts, who rely on conventional sovereign bonds; this is a finding that was conveyed in the initial descriptive statistics when we noted that, on average, the margin of the sovereign bond is higher than that observed in sovereign Sukuk.

Due to the positive correlation between the size of Islamic banking systems and the level of institutional quality within a country $(0.2871)$, we can also conclude that countries with higher institutional quality scores are more likely to tap into the sovereign Sukuk credit market. On a similar note, the negative correlation between institutional quality and the level of debt (-0.2692) reveals that countries that benefit from higher levels of institutional quality tend to rely less on debt markets, and prefer other financing channels.

Finally, the negative correlation between an OIC country's regulation as proxied by the financial market development indicator score and its corresponding level of debt (-0.0458) reveals that the more developed a financial market is, the less it is dependent on debt as a financing medium. Moreover, highly regulated countries with elevated financial market development indicators are more likely to tap into sovereign Sukuk markets than conventional bond markets, as depicted by 
the positive correlation between regulation and the size of Islamic finance systems (0.2306).

Table 5.

Main regression

Table 5 reports our main estimations using the logit model. The determinants of the sovereign target debt security issuance reveal a mixed but significant relationship between a country's economic and financial conditions, debt characteristics and special events that take place within the countries' debt market. We observe that debt maturity is positively correlated with sovereign Sukuk issuance, while issuance size is negatively correlated with Sukuk issuance. We conclude that governments prefer to issue sovereign Sukuk rather than conventional bonds as the horizon of payment periods become higher, while they opt for conventional bonds with larger debts. Interestingly, debt margin is positively correlated with sovereign bond issuance and negatively correlated with sovereign Sukuk, which indicates that Sukuk issues are regarded as safe investments and require lower margins to cover any potential risks, while conventional bonds do not benefit from the same treatment by requiring higher margins.

\begin{tabular}{|c|c|c|c|c|c|c|}
\hline & \multicolumn{6}{|c|}{ Logit Model } \\
\hline & \multicolumn{3}{|c|}{ Islamic Sukuk } & \multicolumn{3}{|c|}{ Conventional Bonds } \\
\hline & Coef & Z-test & P-Value & Coef & Z-test & P-Value \\
\hline Size & -7.271 .476 & -10.79 & 0.000 & 7.271 .476 & 10.72 & 0.000 \\
\hline Margin & -1.405 .382 & -7.65 & 0.000 & 1.405 .374 & 7.65 & 0.000 \\
\hline Tenor & 1.629 .157 & 11.54 & 0.000 & -1.629 .169 & -11.55 & 0.000 \\
\hline Previous Issue & -3.420 .523 & -11.07 & 0.000 & 3.420 .525 & 11.09 & 0.000 \\
\hline Simultaneous Issue & 1.570 .645 & 13.54 & 0.000 & -1.570 .644 & -13.51 & 0.000 \\
\hline Regulation & 4.595 .813 & 14.48 & 0.000 & -4.595 .813 & -14.48 & 0.000 \\
\hline Institutional Quality & 3.205 .975 & 12.37 & 0.000 & -3.205 .975 & -12.34 & 0.000 \\
\hline Institutional Reserves & $-4.66 e-09$ & -7.90 & 0.000 & $4.66 \mathrm{e}-09$ & 7.90 & 0.000 \\
\hline Finance Debt & -.0556077 & -3.75 & 0.000 & .0556077 & 3.75 & 0.000 \\
\hline $\begin{array}{l}\text { Cumulative Finance } \\
\text { Debt }\end{array}$ & .0007608 & 12.67 & 0.000 & -.0007608 & -12.64 & 0.000 \\
\hline Credit Rating & .7439948 & 5.88 & 0.000 & -.7439948 & -5.88 & 0.000 \\
\hline GDP & $1.09 \mathrm{e}-11$ & 7.17 & 0.000 & $-1.09 e-11$ & -7.17 & 0.000 \\
\hline INTEREST & -2.050 .209 & -13.29 & 0.000 & 2.050 .208 & 13.26 & 0.000 \\
\hline INF & -7.235 .354 & -16.20 & 0.000 & 7.235 .142 & 16.44 & 0.000 \\
\hline GDP per capita & -.0060928 & -16.56 & 0.000 & .0060928 & 16.55 & 0.000 \\
\hline IF SIZE & 1.300 .604 & 10.35 & 0.000 & -1.300 .604 & -10.28 & 0.000 \\
\hline FINMART & 2.115 .679 & 10.40 & 0.000 & -2.115 .677 & -10.41 & 0.000 \\
\hline CAPMART & 1.958 .345 & 10.38 & 0.000 & -1.958 .342 & -10.46 & 0.000 \\
\hline R2 & 0.9812 & & & 0.9123 & & \\
\hline Chi2 & 169.51 & & & 167.14 & & \\
\hline $\begin{array}{l}\text { Number of } \\
\text { Observations }\end{array}$ & 745 & & & 745 & & \\
\hline
\end{tabular}

Table 5 reports our main estimations using the Logit model. The determinants of the sovereign target debt security issuance reveal a mixed but definite correlation between a country's economic and financial conditions, debt characteristics, and the special events that take place within the countries' debt market.

We observe that debt maturity is positively correlated with sovereign Sukuk issuance, while issuance size is negatively correlated with Sukuk issuance. We conclude that governments prefer sovereign Sukuk bonds to conventional bonds 
as the horizon of payment periods increases, while they opt for conventional bonds with larger debt volumes. Interestingly, debt margin is positively correlated with sovereign bond issuance and is negatively correlated with sovereign Sukuk, which indicates that Sukuk issuances are regarded as safe investments and require lower margins to cover any potential risks; however, conventional bonds that require higher margins do not benefit from the same treatment.

We also determine that economy size, as represented by GDP, is positively correlated with sovereign Sukuk issuance. We conclude that countries with large economies prefer to issue sovereign Sukuk bonds than sovereign bonds; this confirms hypothesis 2; since large economies have a strong potential to advance and develop their debt markets by venturing into new debt securities, Sukuk may be a perfect candidate for those sophisticated new debt products. Regarding debt market development, our findings are consistent with Eichengreen and Luengnaruemitchai (2004) and Adelegan and Radzewicz-Bk (2009).

\subsection{Analysis}

Our results also show that, regarding financial market development, countries with greater capital markets and/or larger financial markets are more likely to issue sovereign Sukuk. Moreover, countries with larger Islamic finance systems are also more inclined towards sovereign Sukuk issuance. These results indicate that countries with a higher developed financial market tend to rely more on Sukuk issuance than sovereign conventional bonds, which supports hypothesis 3. Financial and capital market and Sukuk market intermediation appear to complement each other. Regarding country credit ratings, our results show that countries with a higher credit rating are more likely to issue Sukuk bonds.

This strong preference for issuing sovereign Sukuk rather than bonds when countries have higher credit ratings, larger capital and financial markets, and/ or a higher level of Islamic finance provide evidence that characteristics such as better credit quality, strong financial position, and the ability to easily meet their financial commitments lead to a preference for issuing sovereign Sukuk rather than bonds as a means of developing current debt markets and diversifying debt products. These findings confirm hypothesis 4 .

Moreover, regarding the correlation between finance debt and the issuance of conventional bonds, results indicate that countries with higher debt ratios are more likely to issue sovereign bonds than Sukuk. Results also reveal the correlation between conventional bonds and cumulative finance debt; i.e. higher levels of cumulative finance debt are coupled with sovereign bond issues.

As far as the effect of macroeconomic instability is concerned, we observe that countries with higher inflation rates are more likely to issue sovereign bonds over Sukuk. Overall, our results suggest that countries with economic frictions and a frail economic system marked by higher inflation rates, lower GDP, and lower GDP per capita are less interested in tapping into the Sukuk market for newlydeveloped debt tools and prefer to issue conventional bonds in response to their financing needs.

The degree of finance and market regulation reveals a tendency towards issuing Islamic Sukuk rather than sovereign bonds, which is indicative of the 
preference of countries with strong finance and market regulation indices. Similarly, countries with higher levels of institutional quality are more likely to opt for sovereign Sukuk issuance than sovereign bonds. Both results suggest an association between good financial indicators and the issue of sovereign Sukuk. Regarding institutional reserves, countries with lower reserves are more likely to opt for conventional bonds and are less interested in Sukuk.

Regarding the impact of specific events, such as previous sovereign Sukuk issuance within the same year, simultaneous sovereign Sukuk and bond issuance, or historic sovereign default, results indicate that countries with previous Sukuk issuance within the last three years are less likely to issue Sukuk within the year, while those with simultaneous issuance of both Sukuk and bonds are more likely to issue Sukuk; this partially confirms hypothesis 5. It remains unclear whether previous sovereign defaults, reported in the history of participating OIC countries, have an impact on the preference of sovereign Sukuk over conventional bonds.

Overall, the Sukuk market appears to be the dominant choice of countries with developed and advanced financial markets, better financial indicators, strong economic conditions and backgrounds, and higher macro and microeconomic indicators. Sovereign Sukuk issuers, however, struggle to gain access to the longterm debt market compared to their counterpart sovereign bond issuers; this may be because Sukuk is relatively new to international debt markets. These findings support hypothesis 1 in that both internal and external factors matter when determining a government's choice of sovereign debt.

\section{CONCLUSION AND RECOMMENDATION}

\subsection{Conclusion}

Our main objective was to examine the relative determinants of conventional sovereign debt vs sovereign Sukuk. Previous research lacks understanding of the factors that influence issuers' choice between sovereign Sukuk and sovereign bonds. We attempted to fill this gap by analysing the reasons that governments prefer to issue sovereign Sukuk than sovereign bonds. Our study focused on 745 debts (143 sovereign Sukuk and 602 sovereign bonds) issued by 16 Muslim countries (members of the OIC), observed during the period 1995-2015.

It is evident that factors for the choice that governments regarding the issuance of sovereign Sukuk or sovereign bonds are different. Countries with developed financial markets, strong economic indicators, high credit quality, and sustainable financial positions are more likely to issue sovereign Sukuk than sovereign bonds to develop and diversify their financial markets through the promotion of new debt products. However, countries with weaker economies and frail financial positions are more likely to opt for the issuance of sovereign bonds. Weaker economies appear to have neither the willingness nor the financial means to develop new debt instruments. Therefore, they choose the classic debt market. Our findings also provide evidence that sovereign Sukuk is larger and has longer maturity. However, sovereign bonds are smaller but have a higher margin.

Our paper contributes to the existing economic and finance literature by providing evidence of the motives of national governments' issuance of sovereign Sukuk or conventional bonds. Moreover, we believe this is the first paper to 
examine the factors determining governmental choice between sovereign Sukuk or conventional bonds in 16 OIC countries.

In terms of the direction for future research, with additional data becoming readily available, we can further investigate the determinants of sovereign debt issuance by examining the various structures of bonds and Sukuk, given the fact that multiple types of Sukuk contracts exist (Ijarah, Musharakah, Murabahah, Istisna, Salam, Wakalah, and Mudarabah); it may be very interesting to look at the possible reasons for issuing different types of Sukuk and whether those reasons vary according to the type of Sukuk issued. Moreover, it may be interesting to study the debt security choices within various sectors. Finally, a further categorisation may be considered - looking at sovereign debt from two different perspectives: internal debt versus external debt.

\subsection{Recommendation}

Given the findings of this research, we suggest several policy recommendations. The authorities of a Sukuk issuing country should ascertain its macroeconomic stability to gain better access to international markets to attract investors to invest in Sukuk, which is risker than investing in conventional bonds. As market shares increase, improvements must be made to the Sukuk product range and risk-return profiles. A dominant market share will eventually lead to new products that will conform to the higher ideals of Islamic finance. Authorities need to show vigilance in not only endorsing non-asset-based Sukuk structures but also asset-backed Sukuk structures without placing too much emphasis on rating agency attitudes. As such, OIC countries may develop their own Islamic ratings agency, which will offer better terms and conditions for Sukuk issuance due to better Shariah knowledge and requirements for Islamic finance.

\section{REFERENCES}

Azmat, S., Skully, M., Kym, B., 2014. Issuer's Choice of Islamic Bond Type. Pac. Basin Financ. J. 28, 122-135.

Byoun, S., 2008. How and when do Firms adjust their Capital Structures toward Targets? J. Financ., 63, 3069-3096.

Eichengreen, B and P. Luengnaruemitchai. 2004. Why Doesn't Asia have Bigger Bond Market. NBER Working Paper No. 10576 (Cambridge, Massachusetts: National Bureau of Economic Research).

Fama, E.F., French, K.R., 2002. Testing Trade-off and Pecking Order Predictions about Dividends and Debt. Rev. Finance. Stud., 15, 1-33.

Frank, M.Z., Goyal, V.K., 2003. Testing the Pecking Order Theory of Capital Structure. JFE., 67, 217-248.

Gelos, G.R., Sahay, R., Sandleris, G., 2011. Sovereign borrowing by Developing Countries: What Determines Market Access? J. Int. Econ., 83, 243-254.

Godlewski, C. J., Turk-Ariss, R., \& Weill, L. 2013. Sukuk vs. Conventional bonds: A Stock Market Perspective. Journal of Comparative Economics, 41, 745-761. 
Godlewski, C. J., Turk-Ariss, R., \& Weill, L. 2016. What Influences Stock Market Reaction to Sukuk Issues? The Impact of Scholars and Sukuk Types. Journal of Economic Behavior \& Organization, (forthcoming).

Grassa, R. and Miniaoui, H. 2017. Corporate choice between Conventional Bond and Sukuk Issuance Evidence from GCC Countries. Research in International Business and Finance (forthcoming).

Grigorian, D., 2003. On the Determinants of First-Time Sovereign Bond Issues. IMF Working Paper No. 03/184. Thomas (2009).

Huang, R., Ritter, J.R., 2009. Testing Theories of Capital Structure and Estimating The Speed of Adjustment. J. Financ. Quant. Anal., 44, 237-271.

Klein, P.O., Weill, L., 2015. Why Do Companies Issue Sukuk? Rev. Financ. Econ., 31, 26-33.

Lemmon, M.L., Roberts, M.R., Zender, J.F., 2008. Back to the beginning: Persistence and The Cross Section of Corporate Capital Structure. J. Financ. 63, 1575-1608.

Mohamed, et al., 2015. Why Do Issuers Issue Sukuk or Conventional Bond? Evidence from Malaysian Listed Firms using Partial Adjustment Models. Pac. Basin Finance J., 34, 233-252.

Nagano, M., 2016. Who Issues Sukuk and When? An Analysis of Islamic Bond Issuance Determinants. Rev. Financ. Econ., 31, 45-55.

Nagano, M., 2017. Sukuk Issuance and Information Asymmetry: Why Do Firms Issue Sukuk? Pac. Basin Finance J., 42, 142-157.

Presbitero, A.F., Ghura, D., Adedeji, O., Nije, L., 2016. Sovereign Bonds in Developing Countries: Drivers of Issuance and Spreads. Rev. Dev. Financ. 6, $1-15$.

Said, A., \& Grassa, R. 2013. The Determinants of Sukuk Market Development: Does Macroeconomic Factors Influence The Construction of Certain Structure of Sukuk? Journal of Applied Finance and Banking, 3(5), 251-267. 
This page is intentionally left blank 